\title{
Erratum to: The prevalence of medical nomadism of the followed patients in rheumatology
}

Aziza Boudali - Rachid Bahiri - Ihssane Hmamouchi •

Redouane Abouqal • Najia Hajjaj Hassouni

Published online: 17 August 2011

(C) Springer-Verlag 2011

Erratum to: Rheumatol Int

DOI 10.1007/s00296-011-1823-0

The author name in the published article was misspelled as

"Abouqual". The correct author name is "Abouqal".

The online version of the original article can be found under doi:10.1007/s00296-011-1823-0.

A. Boudali $(\bowtie) \cdot$ R. Bahiri · I. Hmamouchi · R. Abouqal ·

N. Hajjaj Hassouni

Rabat-Sale, Morocco

e-mail: a.boudali@yahoo.fr 